\title{
Sexual Survey: A Cross-cultural Perspective
}

\author{
Fernando Luiz Cardoso ${ }^{1}$ \\ Universidade do Estado de Santa Catarina
}

\begin{abstract}
This is a comparative cross-cultural investigation and an analysis of the sexual life of presumably middle class college students of four countries: Israel, Colombia, Canada and Brazil. Post graduation-level students of the Institute for Advanced Studies in Human Sexuality (IASHS) in San Francisco collected the data as a PhD requirement. The data analysis revealed that, even though members of various sample groups speak different languages and belong to distinct cultures, they exhibit some similar aspects in their sexual life. Additionally, comparisons were made with the data of the NHSLS Report (USA) in a few selected topics and, again, more similarities were found among the international university students.
\end{abstract}

Key words: cross-cultural; sexuality; social class; sexual history.

\section{Pesquisa Sexual: Uma Perspectiva Cultural Contrastante}

\begin{abstract}
RESUMO - Esta é uma investigação transcultural e uma análise da vida sexual de estudantes universitários provavelmente oriundos da classe média de quatro países: Israel, Colômbia, Canadá e Brasil. Estudantes de pós-graduação do Instituto de Estudos Avançados em Sexualidade Humana (IASHS) em São Francisco coletaram os dados como um dos requisitos do programa de doutorado. A análise dos dados revelou que, apesar dos indivíduos da amostra falarem diferentes línguas e pertencerem a distintas culturas, eles exibem alguns aspectos similares em sua vida sexual. Além disso, comparações foram feitas com os dados do Relatório NHSLS (USA) em alguns tópicos e, novamente, mais similaridades foram encontradas em relação aos estudantes universitários internacionais.
\end{abstract}

Palavras-chave: transculturalidade; sexualidade; classe social; histórico sexual.

Kinsey, Pomeroy and Martin (1948) were the first to demonstrate sexual differences among social classes in terms of sexual history in USA. In the 1990's, scholars (Janus \& Janus, 1993; Laumann, Gagnon, Michael \& Michaels, 1994; Michael, Gagnon, Laumann \& Kolata, 1994; etc.) enhanced our understanding of this phenomenon in USA by using larger and more representative samples. Still, considering that there is very limited cross-cultural research in human sexuality and that there is no hegemony in human sexual behavior in general, we simply do not have much information about relative cross-cultural human sexual behavior. Obstacles in cross-cultural investigation usually include language and nuance, as well as varying social organization. Thus crosscultural research is one of the biggest challenges for social and human sciences because it jeopardizes our sense of perception, cross-cultural analyses of fieldwork data can easily take us in two different ways: first, biased interpretations of similarities and variations that could show up by chance; and second, blindness to the presence of phenomenon that could be hidden in different and unknown cultural contexts.

Human sexual behavior is purportedly very different from one individual to another (Bell \& Weinberg, 1978; Kinsey et al., 1948; Lago, 1999; Money, 1998; Stoller, 1993) or very different from one culture to another (Endogan, 2001; Ford \& Beach, 1951; Fry, 1982; Geertz, 1978; Knauft, 1986; Parker, 1991; Reiss, 1986). However "cultural globalization" seems

1 Endereço: Rua Benevenuta Bartlet James, 69, Florianópolis, SC, Brasil. E-maild2flc@udesc.br to blend behavior across cultures within the middle class, while also increasing distinctions between classes within a single culture. Everyday middle class professional people around the world are sharing increasingly similar life experiences, while the life experiences of this expanding world middle class evolve away from their lower class cultural peers in their own countries. In some first world countries, dominated by a huge middle class, sometimes it is difficult to distinguish these social classes differences among people who look somewhat similar but behave differently in their social ethos. On the other hand, the cultural and sexual diversity among social classes is easily perceived in the developing countries where there is no clearly dominant middle class (Allyn, 1993; Cardoso, 2002; Cardoso \& Werner, 2004; Fry, 1995; Jackson, 1999; Necef, 1992).

For better understanding the phenomenon of sexual variety among middle class as a cross-cultural experience, this research compared secondary data on sexual behavior of college students in Israel, Colombia, Canada and Brazil from IASHS archives. Does the notion of "cultural globalization" or "educational access" affect the sexual behavior on people around the world (Rostler \& Mundell, 2001)? Are historically different communities becoming increasingly similar to global media, real-time communication, the internet, social trends, etc. unite different people in a common global experience (Cardoso, 1994)? In essence, are the individual sexual histories of middle class Brazilians, middle class Israelis, and middle class Colombians more similar to each other across cultures than they are between their own countrymen of a different social stratum? 


\section{F. L. Cardoso}

\section{Method}

\section{Sample}

These sexual investigations were conducted by different researchers (IASHS graduate students) between 1982 to 2000 as a PhD. program requirement. The surveys, designed to measure sexual attitudes and behavior (IASHS, 1977), were translated to Hebrew, Spanish, French and Portuguese by Wattelman (1995), Villegas (1999), Edmond (1982) and Cardoso (2000), respectively. Males ranged in age from 16 to 46 years, with a mean of 21.6 years. Females ranged in age from 16 to 44 years, with a mean of 21.8 years.

The Brazilian, Colombian and Canadian samples contain more Christians than those from Jewish Israel. Latinos have a higher percentage of atheism. Respondents were largely single, with the exception of Israeli and Brazilian samples that presented a higher age mean. The same relation between higher mean age and higher percentage of marital status was also stronger among Brazilian women who were older on average by 6.1 years. Table 1 illustrates the international samples profile. Virtually, all participants were college students except in Brazil, where part-time students make up a large part of the sample.

Israeli sample was collected by Wattleman in 1995 and ultimately consisted of 100 (50 male/50 female) college students enrolled in a BA Law Degree program at the Uni- versity of Jerusalem. For those students who were interested in voluntarily participating after explanation and solicitation by their professor (most participated), questionnaires were distributed and returned at the beginning of the next class meeting (Wattleman, 1995).

Colombian sample was collected by Villegas in 1999 and consisted of 100 (50 males/50 females) college students enrolled at several colleges in Manizales, Columbia. Research assistants, familiar with the survey, randomly solicited (during a 20-day period in October 1999) students on campuses to complete the survey. Only participants' student status was verified. Soliciting continued for several days until a sufficient number of competed surveys were received (Villegas, 1999).

Canada sample was collected by Edmond in 1982. The sample ultimately consisted of 100 (50 males/50 females) college students enrolled in one of four philosophy classes in their first semester at Le College de L'Abititi-Temiscamingue in Rouyn, Noranda, P. Quebec. The professor, Michael Gey, gave students time at the beginning of class to complete the questionnaire, and the questionnaires were collected upon completion (Edmond, 1982).

Brazilian sample was collected by Cardoso in 2000 and consisted of 100 (50 males/50 females) college students enrolled in teacher education programs at Santa Catarina Federal University and Santa Catarina State University. The questionnaire was administered individually in small groups

Table 1. Basic samples profile.

\begin{tabular}{|c|c|c|c|c|c|c|c|c|}
\hline Countries & \multicolumn{2}{|c|}{ Israel } & \multicolumn{2}{|c|}{ Colombia } & \multicolumn{2}{|c|}{ Canada } & \multicolumn{2}{|c|}{ Brazil } \\
\hline Flags & & & & & & & & \\
\hline Variables & \multicolumn{2}{|c|}{$\begin{array}{c}\text { Wattelman } \\
\text { (1995) }\end{array}$} & \multicolumn{2}{|c|}{$\begin{array}{c}\text { Villegas } \\
\text { (1999) }\end{array}$} & \multicolumn{2}{|c|}{$\begin{array}{c}\text { Edmond } \\
\text { (1982) }\end{array}$} & \multicolumn{2}{|c|}{$\begin{array}{c}\text { Cardoso } \\
(2000)\end{array}$} \\
\hline Sex & Male & Fem. & Male & Fem. & Male & Fem. & Male & Fem. \\
\hline $\mathrm{N}$ & 50 & 50 & 50 & 50 & 50 & 50 & 50 & 50 \\
\hline 1. Age (mean) & 23.8 & 22.4 & 22 & 21 & 17.1 & 17.5 & 23.4 & 26.4 \\
\hline \multicolumn{9}{|l|}{ 2. Race (\%): } \\
\hline White & $100 \%$ & $100 \%$ & $28 \%$ & $28 \%$ & $100 \%$ & $100 \%$ & $94 \%$ & $94 \%$ \\
\hline black & & & $1 \%$ & $1 \%$ & & & $2 \%$ & $2 \%$ \\
\hline hispanic & & & $63 \%$ & $63 \%$ & & & & $4 \%$ \\
\hline other & & & $8 \%$ & $8 \%$ & & & $4 \%$ & \\
\hline \multicolumn{9}{|l|}{ 3. Religion (\%): } \\
\hline catholic & & & $76 \%$ & $88 \%$ & $96 \%$ & $98 \%$ & $66 \%$ & $72 \%$ \\
\hline protestant & & & $2 \%$ & & & & $8 \%$ & $10 \%$ \\
\hline jewish & $98 \%$ & $99 \%$ & & & $2 \%$ & & & \\
\hline other & $2 \%$ & & $4 \%$ & $2 \%$ & $2 \%$ & & $8 \%$ & $10 \%$ \\
\hline no religion & & $1 \%$ & $18 \%$ & $10 \%$ & & $2 \%$ & $18 \%$ & $8 \%$ \\
\hline \multicolumn{9}{|l|}{ 4. Marital status (\%): } \\
\hline single & $50 \%$ & $57 \%$ & $88 \%$ & $98 \%$ & $100 \%$ & $100 \%$ & $78 \%$ & $48 \%$ \\
\hline married & $37 \%$ & $29 \%$ & $12 \%$ & $2 \%$ & & & $22 \%$ & $52 \%$ \\
\hline
\end{tabular}


over a two-weeks period. Students were invited by their professors to complete the survey, and they were given sufficient time to complete the entire survey. No students refused to complete the survey, and all surveys were immediately collected upon completion (Cardoso, 2000).

The data were organized and analyzed in this paper only in terms of percentages and means due to the fact that I had access only to the students' final printed reports. Important quantitative information as the number of respondents for each question, standard deviation, $\mathrm{X}$ square, data distribution and so on were not available on their reports, so that statistical testing was compromised in my analysis. In order to identify differences of countries and sexes, I have arbitrarily decided to consider only the significant differences ("significant" differences in percentage $=$ difference in percentage between groups $>10 \%$ and "significant" differences in term of means $=$ difference in terms of mean between groups $>$ maximum value - minimum value divided by 4). No considerations of ethnicity, religious beliefs, sexual orientation or another demographic factor were made in selecting participants at all.

Social research often takes one of two extreme forms. Either researcher completely disregard quantitative data, relying entirely on "anecdotal" evidence gathered haphazardly, or they insist on using large representative samples with variables that have been carefully validated and have high reliability coefficients. These two extremes may not be the best way to do social and sexual research. Science is akin to the process of natural selection. Researchers come up with new ideas (mostly variants of old ideas), and then submit them to "selection pressures" in the form of systematic experiments or other tests. As complexity theorists have pointed out (based on experimental studies), the emergence of new phenomena is most likely where selection pressures are neither too lax nor too rigid (Johnson, 2001; Waldrop, 1992). If too lax, then too many unproductive directions are taken. If too rigid, then new directions are made impossible. Likewise, in science, anecdotal evidence (lax selection) results in a confusing free-for-all that permits too many bad ideas to flourish, while overly rigid criteria for evidence inhibit the emergence of new theories. To be sure, we need all types of sex research. In medicine, for example, the appearance of a new disease or cure often begins with anecdotal reports. Then small samples and simple experiments sort out the most productive lines of inquiry. Finally, large systematic studies evaluate more exactly how much a given remedy improves health, what are the risks, and what net economic returns might be. Discouraging "middle-level" evidence, disrupts perhaps, the most important step in generating productive ideas.

This study uses "middle-level" evidence based on secondary data. Samples are neither representative of their countries, nor large, and variables have not all been tested for validity and reliability. But neither are samples haphazard nor variables invented ad hoc.

\section{Results}

\section{Social rules and cultural beliefs profile of samples}

In terms of frequency of attendance at religious services, the majority Israeli and Colombians students, in general, never go to religious services $(60.5 \%$ and $61.5 \%$, respectively), followed by Brazilians (21\%). There is no important difference between genders among international students samples $(>10 \%)$. Women as a whole are slightly more likely than men to go to religious services. Exceptions were found on Brazilian sample, where more males (30\%) never go to religious services in relation to females (12\%).

In relation to religious attitudes, Israeli students self-evaluate as more liberal (70\%), followed by Colombians $(55 \%)$, Brazilians (45\%) and Canadians (35\%). In terms of gender, more males evaluate themselves as being more liberal than females $(>10 \%)$, except among Israeli women, where they seem to be more liberal $(>10 \%)$. In relation to political attitudes, Israeli students again see themselves as more liberal (65\%), followed by Colombians (49\%), Canadians and Brazilians (40\% and $37 \%$, respectively). In terms of gender, males think of themselves as more liberal than females, except, again, in Israel, where both sexes' scores are similar. In relation to sex attitudes, Israeli and Colombian students think of themselves as more liberal (54.5\% and 55\%), followed by Brazilians and Canadians (45\% and 39\%, respectively). In terms of gender, males think themselves as more liberal than females, except again in Israel, where women tend to be more liberal than men $(>10 \%)$. The liberalness of Israeli women is probably related to a more egalitarian educational system.

All countries are very similar on most eight aspects of sexual human rights. We analyzed three of them. The first one is "the right to not be exposed to sexual material or behavior". Israeli and Canadians' scores are higher (95\% and 98\%, respectively), followed by Brazilians (82\%) and Colombians (73\%). In terms of gender, only Colombian men showed less agreement (males $64 \%$ and females $82 \%$ ). The second is "the right of sexual entertainment, freely available in the market place, including sexually explicit materials dealing with the full range of sexual behavior" .Canadian, Colombians and Israeli students scored higher $(98 \%, 90 \%$, and $85 \%$, respectively); however, Brazilians showed a much more conservative position in this subject with only $48.5 \%$ of them agreeing $(>10 \%)$. In terms of gender, men in Israel and Brazil seem to be more liberal in terms of sex as entertainment than females $(>10 \%)$. The third is "the recognition by society that every person, partnered or unpartnered, has the right to pursuit a satisfying consensual socio-sexual life free from political, legal or religious interference and there need to be mechanisms in society where the opportunities of socio-sexual activities are available to the following; disabled persons; chronically ill persons; those incarcerated in prisons, hospitals or institutions; those disadvantaged due to age, lack of physical attractiveness or social skills; the poor and the lonely". Canadians, Colombians and Israeli students scored higher $(98 \%, 94 \%$ and $90.5 \%$, respectively) followed by Brazilians ( $81 \%)$. No important difference in terms of gender $(>10 \%)$ was found related to this sexual right. Some details on Table 2.

\section{International samples sexual history profile}

Sex in their personal lives is very important to male and female students. More Colombians (71\%), followed by Israelis $(50.5 \%)$ and Brazilians (42\%) evaluate their sexual life as above average, while only $14 \%$ of Canadians think the same. 


\section{F. L. Cardoso}

Table 2. Samples' social rules and cultural believes profile in percentage.

\begin{tabular}{|c|c|c|c|c|c|c|c|c|}
\hline Countries & \multicolumn{2}{|c|}{ Israel } & \multicolumn{2}{|c|}{ Colombia } & \multicolumn{2}{|c|}{ Canada } & \multicolumn{2}{|c|}{ Brazil } \\
\hline \multicolumn{9}{|l|}{ Flags } \\
\hline Variables & \multicolumn{2}{|c|}{$\begin{array}{l}\text { Wattelman } \\
\text { (1995) }\end{array}$} & \multicolumn{2}{|c|}{$\begin{array}{l}\text { Villegas } \\
\text { (1999) }\end{array}$} & \multicolumn{2}{|c|}{$\begin{array}{l}\text { Edmond } \\
\text { (1982) }\end{array}$} & \multicolumn{2}{|c|}{$\begin{array}{l}\text { Cardoso } \\
(2000)\end{array}$} \\
\hline Sex & Male & Fem. & Male & Fem. & Male & Fem. & Male & Fem. \\
\hline $\mathrm{N}$ & 50 & 50 & 50 & 50 & 50 & 50 & 50 & 50 \\
\hline \multicolumn{9}{|l|}{ 1. Frequency of religious serv: } \\
\hline weekly & $3 \%$ & $5 \%$ & $15 \%$ & $19 \%$ & $16 \%$ & $26 \%$ & $26 \%$ & $36 \%$ \\
\hline once in a while & $36 \%$ & $39 \%$ & $21 \%$ & $22 \%$ & $76 \%$ & $68 \%$ & $44 \%$ & $52 \%$ \\
\hline never & $63 \%$ & $58 \%$ & $64 \%$ & $59 \%$ & $8 \%$ & $6 \%$ & $30 \%$ & $12 \%$ \\
\hline \multicolumn{9}{|l|}{ 2. Religion attitudes: } \\
\hline more liberal & $64 \%$ & $76 \%$ & $68 \%$ & $42 \%$ & $42 \%$ & $28 \%$ & $56 \%$ & $34 \%$ \\
\hline more conservator & $34 \%$ & $23 \%$ & $32 \%$ & $56 \%$ & $58 \%$ & $72 \%$ & $38 \%$ & $66 \%$ \\
\hline \multicolumn{9}{|l|}{ 3. Political attitudes: } \\
\hline more liberal & $64 \%$ & $66 \%$ & $54 \%$ & $44 \%$ & $46 \%$ & $34 \%$ & $48 \%$ & $26 \%$ \\
\hline more conservator & $35 \%$ & $33 \%$ & $46 \%$ & $50 \%$ & $54 \%$ & $66 \%$ & $52 \%$ & $74 \%$ \\
\hline \multicolumn{9}{|l|}{ 4. Sex attitudes: } \\
\hline more liberal & $45 \%$ & $64 \%$ & $64 \%$ & $46 \%$ & $44 \%$ & $34 \%$ & $56 \%$ & $34 \%$ \\
\hline more conservator & $55 \%$ & $35 \%$ & $36 \%$ & $52 \%$ & $56 \%$ & $66 \%$ & $44 \%$ & $66 \%$ \\
\hline \multicolumn{9}{|c|}{$\begin{array}{l}\text { 5. Agree with the right to not be exposed to } \\
\text { sexual mater: }\end{array}$} \\
\hline agree & $95 \%$ & $95 \%$ & $64 \%$ & $82 \%$ & $98 \%$ & $98 \%$ & $78 \%$ & $86 \%$ \\
\hline disagree & $5 \%$ & $5 \%$ & $36 \%$ & $14 \%$ & $2 \%$ & $2 \%$ & $22 \%$ & $14 \%$ \\
\hline \multicolumn{9}{|l|}{$\begin{array}{l}\text { 6. Agree with the right to sexual } \\
\text { entertainment: }\end{array}$} \\
\hline agree & $92 \%$ & $78 \%$ & $88 \%$ & $92 \%$ & $98 \%$ & $98 \%$ & $54 \%$ & $43 \%$ \\
\hline disagree & $7 \%$ & $21 \%$ & $12 \%$ & $6 \%$ & $2 \%$ & $2 \%$ & $46 \%$ & $57 \%$ \\
\hline \multicolumn{9}{|c|}{$\begin{array}{l}\text { 7. Agree with the universal right to human } \\
\text { sexuality: }\end{array}$} \\
\hline agree & $92 \%$ & $89 \%$ & $94 \%$ & $94 \%$ & $98 \%$ & $98 \%$ & $84 \%$ & $78 \%$ \\
\hline disagree & $8 \%$ & $11 \%$ & $6 \%$ & $2 \%$ & $2 \%$ & $2 \%$ & $16 \%$ & $22 \%$ \\
\hline
\end{tabular}

Both males and females surveyed think their sex life is similar in Colombia and Canada while in Israel and Brazil more men $(>10 \%)$ than women surveyed think their sex life is above average. Formal sexual education was part of most of the samples in their educational experience, but there are variations. 93\% of Colombians, $80 \%$ of Brazilians, $64 \%$ of Canadians and only $48 \%$ of Israelis have had formal sexual education. Males and females surveyed through sexual education programs already knew most of such information. Probably, this evaluation was related to biological and medical profiles of sex education, which emphasized sex as a natural and reproductive behavior.

Regarding sexual information, Brazilian (mean age 10.0), Colombian (mean age 10.3) and Israeli students (mean age 11.0), on average, learned earlier about sex-intercourse than Canadians (mean age 13.4, maximum value - minimum value divided by 4). Regarding the age when they learned about masturbation, Brazilians (mean age 11.1) and Colombians (mean age 11.3), on average, learned earlier than others. In terms of 
gender, females learned later about masturbation than males (maximum value - minimum value divided by 4). About sexintercourse, Brazilians (mean age 10.0), Colombians (mean age 10.3) and Israelis (mean age $11.0 \%$ ) learned earlier than Canadians (mean age 13.4, maximum value - minimum value divided by 4). Regarding the age when they knew about the clitoris, Latinos learned earlier: Colombians (mean age 12.2) and Brazilians (mean age 13.2) followed by Israelis (mean age 14.5).
Masturbation, according to Kinsey's definition (1948), is a deliberate self-stimulation which effects sexual arousal. In terms of masturbation, more Canadians said they have never masturbated (39\%), followed by Colombians $(27 \%)$, Brazilians (22\%) and Israelis (19.5\%). However, there is no significant variation in terms of mean age of the first orgasm during their first masturbation among Colombians (mean age 13.2), Brazilians (mean age 13.4) and Canadians (13.8), Israelis being a little older in this experience (14.5).

Table 3. Sexual history profile.

\begin{tabular}{|c|c|c|c|c|c|c|c|c|}
\hline Countries & \multicolumn{2}{|c|}{ Israel } & \multicolumn{2}{|c|}{ Colombia } & \multicolumn{2}{|c|}{ Canada } & \multicolumn{2}{|c|}{ Brazil } \\
\hline \multicolumn{9}{|l|}{ Flags } \\
\hline Variables & \multicolumn{2}{|c|}{$\begin{array}{c}\text { Wattelman } \\
\text { (1995) }\end{array}$} & \multicolumn{2}{|c|}{$\begin{array}{l}\text { Villegas } \\
(1999)\end{array}$} & \multicolumn{2}{|c|}{$\begin{array}{l}\text { Edmond } \\
\text { (1982) }\end{array}$} & \multicolumn{2}{|c|}{$\begin{array}{l}\text { Cardoso } \\
(2000)\end{array}$} \\
\hline Sex & Male & Fem. & Male & Fem. & Male & Fem. & Male & Fem. \\
\hline $\mathrm{N}$ & 50 & $\mathbf{5 0}$ & 50 & 50 & 50 & 50 & $\mathbf{5 0}$ & 50 \\
\hline \multicolumn{9}{|l|}{ 1. How important is sex for you? } \\
\hline slightly important & & $7 \%$ & & $6 \%$ & & $4 \%$ & $4 \%$ & $4 \%$ \\
\hline important & $95 \%$ & $92 \%$ & $90 \%$ & $98 \%$ & $100 \%$ & $96 \%$ & $96 \%$ & $96 \%$ \\
\hline \multicolumn{9}{|l|}{ 2. Personal sexual satisfaction } \\
\hline average & $33 \%$ & $53 \%$ & $24 \%$ & $24 \%$ & $84 \%$ & $86 \%$ & $71 \%$ & $81 \%$ \\
\hline above average & $57 \%$ & $44 \%$ & $71 \%$ & $71 \%$ & $16 \%$ & $12 \%$ & $47 \%$ & $37 \%$ \\
\hline \multicolumn{9}{|l|}{ 3. Had sexual education? } \\
\hline yes & $43 \%$ & $53 \%$ & \multirow{2}{*}{$100 \%$} & $86 \%$ & $68 \%$ & $60 \%$ & $72 \%$ & $88 \%$ \\
\hline no & $57 \%$ & $47 \%$ & & $14 \%$ & $32 \%$ & $40 \%$ & $28 \%$ & $12 \%$ \\
\hline \multicolumn{9}{|l|}{ 4. Age when learned about sex-intercourse? } \\
\hline mean & 11.0 & 11.0 & 10.1 & 10.5 & 13.8 & 13.0 & 9.9 & 10.1 \\
\hline \multicolumn{9}{|l|}{ 5. Age when learned about masturbation? } \\
\hline mean & 12.0 & 14.0 & 10.9 & 11.6 & 13.3 & 14.0 & 10.6 & 11.6 \\
\hline \multicolumn{9}{|l|}{ 6. Age when learned about clitoris? } \\
\hline mean & 16.0 & 13.0 & 12.3 & 12.0 & & & 13.1 & 13.3 \\
\hline \multicolumn{9}{|l|}{ 7. Age of first orgasm in masturbation? } \\
\hline never & $8 \%$ & $31 \%$ & $8 \%$ & $46 \%$ & $8 \%$ & $70 \%$ & $0 \%$ & $44 \%$ \\
\hline mean & 13.0 & 16.0 & 11.8 & 14.6 & 13.8 & 13.8 & 12.3 & 14.4 \\
\hline \multicolumn{9}{|l|}{ 8. Age of first heterosexual sex relation? } \\
\hline never & $80 \%$ & $75 \%$ & $4 \%$ & $10 \%$ & $60 \%$ & $68 \%$ & $10 \%$ & $0 \%$ \\
\hline mean & 18.0 & 18.0 & 15.2 & 17.78 & 15.4 & 15.3 & 15.9 & 18.5 \\
\hline $\begin{array}{l}\text { 9. Weekly frequency of masturbation last year: } \\
\text { mean }\end{array}$ & 2.0 & 0.5 & 2.0 & 1.0 & 2.6 & 1.0 & 2.6 & 0.7 \\
\hline $\begin{array}{l}\text { 10. Partners in heterosexual relations last year? } \\
\text { mean }\end{array}$ & 1.7 & 1.7 & 2.0 & 1.5 & 1.5 & 2.0 & 3.5 & 1.4 \\
\hline \multicolumn{9}{|l|}{$\begin{array}{l}\text { 11. Weekly frequency of he-terosexual relations } \\
\text { last year: }\end{array}$} \\
\hline mean & 2.0 & 2.0 & 2.0 & 2.0 & 1.6 & 1.4 & 2.2 & 1.9 \\
\hline \multicolumn{9}{|l|}{ 12. Heterosexual partners have had in your life? } \\
\hline mean & 8.0 & 5.0 & 2.0 & 1.5 & 1.0 & 2.0 & 10.2 & 3.3 \\
\hline
\end{tabular}


Generally, males had their first orgasm through masturbation at a much earlier age than females (maximum value - minimum value divided by 4 ). The most impressive data related to masturbation is that almost half of females never had an orgasm in this situation, as distinct from the males. See Table 3.

According to Kinsey, Pomeroy, Martin and Gebhard (1953), the definition of intercourse is the union of the genitalia of two individual people of opposite sex; but it may also occur in such a non-coital situations as masturbation or homosexual contacts. The majority of Israelis $(77.5 \%)$ and Canadians $(64 \%)$ were virgins, which differed from Latinos in Brazil (5\%) and Colombia (7\%). For those who already had their first heterosexual experience, Canadians (mean age 15.4) followed by Colombians (mean age 16.5) and Brazilians (mean age 17.2) had their first heterosexual sex experience earlier than the Israelis (mean age 18.0, maximum value - minimum value divided by 4 ).

In relation to the weekly frequency of masturbation, last year no significant differences were found among the four countries (maximum value - minimum value divided by 4); however, males masturbate twice as often or more than females in each country. In terms of the number of heterosexual sexual partners last year, Brazilians have a higher number in relation to other nations (mean 2.5 partners). In addition, Brazilian males also have more than twice the number of partners than Brazilian females (mean 3.5 partners). In relation to weekly frequency of heterosexual experiences, last year there were no variations among countries, except younger Canadians. In terms of the number of heterosexual partners in their entire life, Brazilians and Israelis (mean 6.8 and 6.5, respectively) score significantly higher than Colombians and Canadians (mean 1.8 and 1.5, respectively). It shows that older males in these samples had much more opportunity for casual sex than younger ones. In general, males seem to have had more sexual partners for their entire life than females, except Canadian sexually active females, who score higher in this aspect. See Table 3.

\section{Similar data from middle class in USA}

In order to test my standard point of view on this issue I decided to try some comparisons among IASHS international students' data along with a broad representative spectrum of a sexual report developed in the USA.
To compare compatibility among data produced for different researchers is one of the most difficult aspects for quantitative research. In order to support and illustrate my standard point of view on the internationalization of middle-class sexual history, I checked some NHSLS Report data developed in the USA in order to compare them with the international students' data from IASHS files. Conducted by a research team centered at the University of Chicago, the National Health and Social Life Survey (NHSLS) was designed to determine the incidence and prevalence of sexual practices and to place them in their social contexts. Based on personal interviews with a probability sample of 3,432 American women and men between ages of 18 and 59, undertaken by the National Opinion Research Center, this study explores the extent to which sexual conduct and general attitudes toward sexuality were influenced by gender, age, marriage status and other demographic characteristics. Considering that the United States of America represents a large middle professional class environment, it probably would be comparable with my middle class students' samples from Israel, Colombia, Canada and Brazil.

This broad American national survey had respondents ranging in age from 18 to 59 years old of which $45.0 \%$ were males and $55.0 \%$ females. The majority of respondents were Caucasians as in Brazil, Israel and Canada; however, more were Protestants than on international student's samples. Americans in the NHSLS survey attended religious services more frequently than international college students. Different from international student's samples, the majority of respondents were older, married and lived with their partners, reflecting their higher mean age. More details on Table 4.

\section{Discussion}

The first aspect that was possible to compare was related to the importance of sex in respondents' lives. International student respondents were asked on IASHS Survey "How important is sex for you?" For this question there were three possible answers: A -"very important", B - "somewhat important" and C - "slightly important". And NHSLS Report respondents were asked "How often do you think about sex?". For this question there were three similar possible choices: A - "every day", B - "few times a month" and C

Table 4. National Health and Social Life Survey Profile in percentage (Michael et al., 1994).

\begin{tabular}{|c|c|c|c|c|c|c|c|}
\hline \multicolumn{2}{|c|}{ gender } & \multicolumn{2}{|c|}{ age } & \multicolumn{2}{|c|}{ education } & \multicolumn{2}{|c|}{ race/ethnicity } \\
\hline $\begin{array}{c}\text { male } \\
\text { female }\end{array}$ & $\begin{array}{l}45 \% \\
55 \%\end{array}$ & $\begin{array}{l}18-24 \\
25-29 \\
30-39 \\
40-49 \\
50-59\end{array}$ & $\begin{array}{l}16 \% \\
14 \% \\
32 \% \\
23 \% \\
15 \%\end{array}$ & $\begin{array}{c}\text { high school } \\
\text { high school } \\
\text { some college } \\
\text { college } \\
\text { advanced }\end{array}$ & $\begin{array}{c}14 \% \\
29 \% \\
33 \% \\
17 \% \\
7 \%\end{array}$ & $\begin{array}{c}\text { white } \\
\text { black } \\
\text { hispanic } \\
\text { other }\end{array}$ & $\begin{array}{c}76 \% \\
13 \% \\
8 \% \\
3 \%\end{array}$ \\
\hline \multicolumn{2}{|c|}{ religion } & \multicolumn{2}{|c|}{ marital status } & \multicolumn{2}{|c|}{ residential status } & \multicolumn{2}{|c|}{ church attendance } \\
\hline $\begin{array}{l}\text { protestant } \\
\text { catholic } \\
\text { jewish } \\
\text { other } \\
\text { none }\end{array}$ & $\begin{array}{l}55 \% \\
7 \% \\
2 \% \\
5 \% \\
1 \%\end{array}$ & $\begin{array}{c}\text { single } \\
\text { married } \\
\text { divorced } \\
\text { widowed }\end{array}$ & $\begin{array}{c}28 \% \\
54 \% \\
16 \% \\
2 \%\end{array}$ & $\begin{array}{c}\text { noncohabiting } \\
\text { cohabiting } \\
\text { married }\end{array}$ & $\begin{array}{r}9 \% \\
7 \% \\
54 \%\end{array}$ & $\begin{array}{l}\text { weekly } \\
\text { monthly } \\
\text { yearly } \\
\text { never }\end{array}$ & $\begin{array}{l}29 \% \\
17 \% \\
39 \% \\
15 \%\end{array}$ \\
\hline
\end{tabular}


Table 5. Personal importance of sex in percentage.

\begin{tabular}{|c|c|c|c|c|c|}
\hline \multicolumn{2}{|c|}{$\begin{array}{c}\text { NHSLS* } \\
\text { Michael et al.(1994) } \\
\end{array}$} & \multicolumn{2}{|c|}{ Mean International Students Samples } & \multicolumn{2}{|c|}{ Brazil } \\
\hline male $(N)$ & fem. $(N)$ & male $(N)$ & fem. $(N)$ & male $(N)$ & fem. $(N)$ \\
\hline 1544 & 1887 & 200 & 200 & 50 & 50 \\
\hline A $-54 \%$ & $19 \%$ & $54 \%$ & $37 \%$ & $70 \%$ & $48 \%$ \\
\hline B $-43 \%$ & $67 \%$ & $40 \%$ & $49 \%$ & $26 \%$ & $48 \%$ \\
\hline $\mathrm{C}-4 \%$ & $14 \%$ & $6 \%$ & $13 \%$ & $4 \%$ & $4 \%$ \\
\hline \multicolumn{2}{|c|}{ Israel } & \multicolumn{2}{|c|}{ Colombia } & \multicolumn{2}{|c|}{ Canada } \\
\hline male $(N)$ & fem. $(N)$ & male $(N)$ & fem. $(N)$ & male $(N)$ & fem. $(N)$ \\
\hline 50 & 50 & 50 & 50 & 50 & 50 \\
\hline $\begin{array}{c}A-60 \% \\
B-35 \% \\
C-0 \%\end{array}$ & $\begin{array}{c}46 \% \\
46 \% \\
7 \%\end{array}$ & $\begin{array}{l}70 \% \\
30 \%\end{array}$ & $\begin{array}{c}40 \% \\
48 \% \\
6 \%\end{array}$ & $\begin{array}{l}44 \% \\
56 \%\end{array}$ & $\begin{array}{c}28 \% \\
68 \% \\
4 \%\end{array}$ \\
\hline
\end{tabular}

* This is the mean of the sample as a whole.

- "almost never". Table 5 shows every respective sample answer for later comparison and study.

There was an impressive similarity between NHSLS and mean international students percentage from male respondents; whereas, international female students gave a higher importance to sex than American females. However, the general mean between NHSLS (36.5\%) and international students $(45.5 \%)$ for this question shows a higher importance for sex among college people. Considering that $43.0 \%$ of NHSLS sample did not go to college, perhaps a higher education stimulates females to give more importance to sex. While younger Canadian students followed the NHSLS percentages, Brazilians, Israelis and Colombians gave a higher importance to sex.

In relation to masturbation experience, $5.6 \%$ of males and $41.9 \%$ of females among international students' samples never masturbated in their lives, while $41.2 \%$ of males and $64.4 \%$ of females from NHSLS Report at the mean age never did it either. Masturbation was much more common among international male students as well among female international students who had similar but higher percentages than the American Report. This phenomenon could be related to cultural diversity or to a higher educational background of my international samples. According to Michael (1984), these effects of educational parallel Kinsey's findings that better educated people are more likely to masturbate.

For the respondents who used to masturbate, the weekly frequency of masturbation was another aspect possible to compare with the American Report (frequency mean of 1.6 for both NHSLS and for the mean score of international students). A large discrepancy in lower rates of masturbation was found among Brazilian and Israeli women (mean 0.7 and 0.5 , respectively against male's mean 2.6 and 2.0 ), whereas Brazilian and Canadian men had higher frequency rates of masturbation (mean 2.6 and 2.6, respectively; maximum value - minimum value divided by 4 ). The discrepancy between genders was another characteristic of international students' samples, where males had more than the double share of masturbation rates than their female counterparts. Even when the NHSLS Report sample age is controlled, we notice no differences among male and female masturbation frequency among Americans. This could be explained by cultural differences, women's rights or by the older mean age of this sample. See Table 6.

In terms of nationality, there is no difference between NHSLS and the IASHS data, Israelis and Brazilians being more frequent in weekly masturbation.

Table 6. Mean weekly frequency of masturbation.

\begin{tabular}{|c|c|c|c|c|c|c|c|c|c|c|c|}
\hline \multicolumn{2}{|c|}{ NHSLS* } & \multicolumn{2}{|c|}{ Inter. mean } & \multicolumn{2}{|c|}{ Israel } & \multicolumn{2}{|c|}{ Colombia } & \multicolumn{2}{|c|}{ Canada } & \multicolumn{2}{|c|}{ Brazil } \\
\hline \multicolumn{2}{|c|}{ Michael et al. (1994) } & \multicolumn{2}{|c|}{ Iashs students } & \multicolumn{2}{|c|}{ Wattelman (1995) } & \multicolumn{2}{|c|}{$\begin{array}{l}\text { Villegas } \\
\text { (1999) }\end{array}$} & \multicolumn{2}{|c|}{$\begin{array}{c}\text { Edmond } \\
\text { (1982) }\end{array}$} & \multicolumn{2}{|c|}{$\begin{array}{l}\text { Cardoso } \\
(2000)\end{array}$} \\
\hline male & fem. & male & fem. & male & fem. & male & fem. & male & fem. & male & fem. \\
\hline 247 & 301 & 200 & 200 & 50 & 50 & 50 & 50 & 50 & 50 & 50 & 50 \\
\hline 1.5 & 1.7 & 2.3 & 0.8 & 2.0 & 0.5 & 2.0 & 1.0 & 2.6 & 1.0 & 2.6 & 0.7 \\
\hline \multicolumn{2}{|c|}{ both sex } & \multicolumn{2}{|c|}{ both sex } & \multicolumn{2}{|c|}{ both sex } & \multicolumn{2}{|c|}{ both sex } & \multicolumn{2}{|c|}{ both sex } & \multicolumn{2}{|c|}{ both sex } \\
\hline \multicolumn{2}{|c|}{548} & \multicolumn{2}{|c|}{400} & \multicolumn{2}{|c|}{100} & \multicolumn{2}{|c|}{100} & \multicolumn{2}{|c|}{100} & \multicolumn{2}{|c|}{100} \\
\hline \multicolumn{2}{|c|}{$1.6 \mathrm{~b}$} & \multicolumn{2}{|c|}{$1.6 \mathrm{~b}$} & \multicolumn{2}{|c|}{$1.3 \mathrm{a}$} & \multicolumn{2}{|c|}{$1.5 \mathrm{~b}$} & \multicolumn{2}{|c|}{$1.8 \mathrm{c}$} & \multicolumn{2}{|c|}{$1.7 \mathrm{~b}$} \\
\hline
\end{tabular}

*PS. This is the mean of the sample with ages between 18-24 years old.

PS. "significant" differences ( $a, b, c$ in term of means = difference in terms of mean between groups $>$ maximum value (1.8) - minimum value (1.3) divided by 4). 
Since most of male respondents from NHSLS were married, the number of partners in heterosexual relations last year was low. International students had, on average, a higher number of partners than the American did. Brazilian males (mean 3.5) were the most promiscuous of all, followed by Colombians (mean 2.0), Israelis (mean 1.7) and Canadians (mean 1.5). According to Michael, Gagnon, Laumann and Kolata (1994) this situation between NHSLS and international samples made sense since men used to have more partners than women and young people used to have more partners than older ones. As well, those who are young and single (either never got married or no longer married) are far more likely to report having five or more partners within the past 12 months. Thus, marital status is strongly related to lower rates of number of partners. The authors also emphasize that neither educational level nor current religious practice had a pronounced effect on the number of partner rates in the last 12 months. See Table 7.

International students had a higher number of heterosexual partners last year than the NHSLS respondents. Brazilian males scored exceptionally higher.
In relation to weekly frequency of heterosexual relations, international students scored higher than the NHSLS respondents, except for Canadian students who scored lower. According to Michael et al. (1994), the frequency of sex across race, ethnicity, religious affiliation and educational levels did not produce relevant variations in America, whereas Hispanic men used to be somewhat more to likely to report higher frequencies of sexual activities. See Table 8 below.

Regarding the number of heterosexual partners over the whole life span, there was no significant difference among the mean of international students in relation to the NHSLS respondents. Colombians and Canadians had fewer heterosexual partners, Israelis and Brazilians had more. International male students had many more partners. There was a large discrepancy among male students. Brazilian males (mean 10.2), followed by Israeli males (mean 8.0), were the most promiscuous in this comparison, while Canadian males (probably due to their younger average age) were less sexual. According to Michael et al. (1994), considering the accumulation of partners, over the whole adult lifetime, there was a pattern of rising number of partners with higher levels of education. See Table 9.

Table 7. Mean number of partners in heterosexual relations last year.

\begin{tabular}{|c|c|c|c|c|c|c|c|c|c|c|c|}
\hline \multicolumn{2}{|c|}{ NHSLS* } & \multicolumn{2}{|c|}{ Inter. mean } & \multicolumn{2}{|c|}{ Israel } & \multicolumn{2}{|c|}{ Colombia } & \multicolumn{2}{|c|}{ Canada } & \multicolumn{2}{|c|}{ Brazil } \\
\hline \multicolumn{2}{|c|}{ Michael et al. (1994) } & \multicolumn{2}{|c|}{ Iashs students } & \multicolumn{2}{|c|}{ Wattelman (1995) } & \multicolumn{2}{|c|}{$\begin{array}{c}\text { Villegas } \\
(1999)\end{array}$} & \multicolumn{2}{|c|}{$\begin{array}{c}\text { Edmond } \\
(1982)\end{array}$} & \multicolumn{2}{|c|}{$\begin{array}{c}\text { Cardoso } \\
(2000)\end{array}$} \\
\hline male & fem. & male & fem. & male & fem. & male & fem. & male & fem. & male & fem. \\
\hline 1544 & 1887 & 200 & 200 & 50 & 50 & 50 & 50 & 50 & 50 & 50 & 50 \\
\hline 1.4 & 1.0 & 2.2 & 1.6 & 1.7 & 1.7 & 2.0 & 1.5 & 1.5 & 2.0 & 3.5 & 1.4 \\
\hline \multicolumn{2}{|c|}{ both sex } & \multicolumn{2}{|c|}{ both sex } & \multicolumn{2}{|c|}{ both sex } & \multicolumn{2}{|c|}{ both sex } & \multicolumn{2}{|c|}{ both sex } & \multicolumn{2}{|c|}{ both sex } \\
\hline \multicolumn{2}{|c|}{3431} & \multicolumn{2}{|c|}{400} & \multicolumn{2}{|c|}{100} & \multicolumn{2}{|c|}{100} & \multicolumn{2}{|c|}{100} & \multicolumn{2}{|c|}{100} \\
\hline \multicolumn{2}{|c|}{$1.2 \mathrm{a}$} & & & \multicolumn{2}{|c|}{$1.7 b$} & & & \multicolumn{2}{|c|}{$1.8 \mathrm{~b}$} & \multicolumn{2}{|c|}{$2.5 \mathrm{c}$} \\
\hline
\end{tabular}

*PS. This is the mean of the sample as whole.

PS. "significant" differences $(a, b, c)$ in term of means = difference in terms of mean between groups $>$ maximum value (2.5) - minimum value (1.2) divided by 4).

Table 8. Mean weekly frequency of heterosexual relations last year.

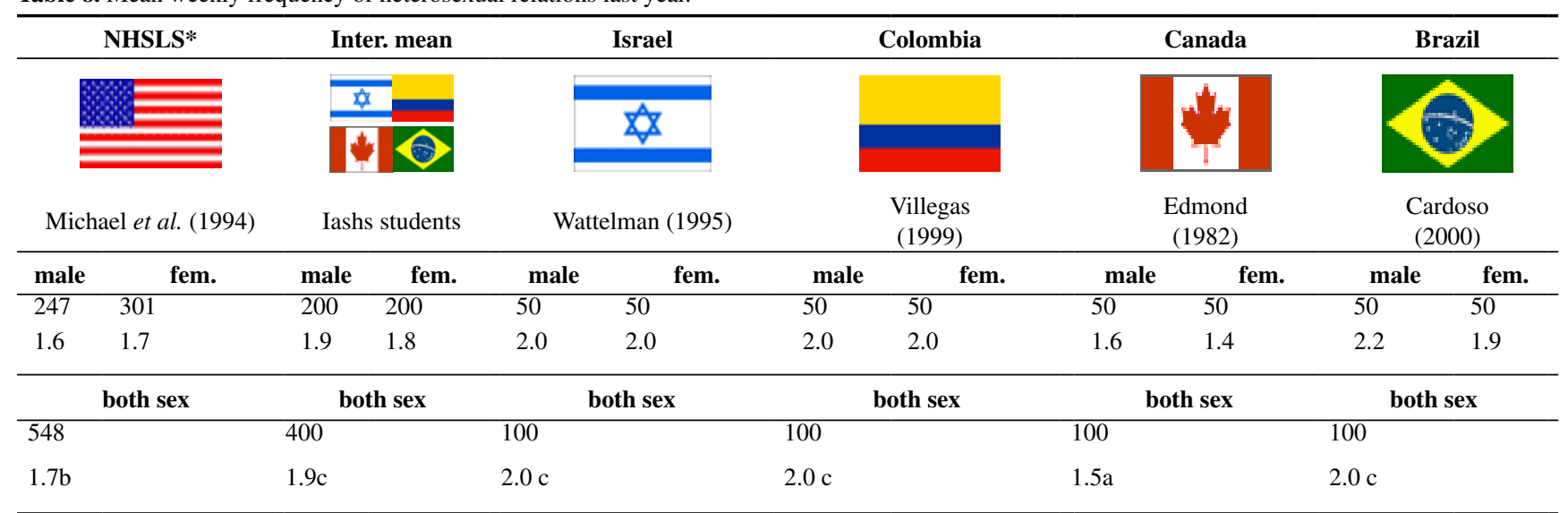

*PS. This is the mean of the sample with ages between $18-24$ years old.

PS. "significant" differences $(a, b, c)$ in term of means = difference in terms of mean between groups $>$ maximum value (2.0) - minimum value (1.5) divided by 4$)$. 
Table 9. Mean number of partners in heterosexual relations in whole life.

\begin{tabular}{|c|c|c|c|c|c|c|c|c|c|c|c|}
\hline \multicolumn{2}{|c|}{ NHSLS* } & \multicolumn{2}{|c|}{ Inter. mean } & \multicolumn{2}{|c|}{ Israel } & \multicolumn{2}{|c|}{ Colombia } & \multicolumn{2}{|c|}{ Canada } & \multicolumn{2}{|c|}{ Brazil } \\
\hline \multicolumn{2}{|c|}{ Michael et al. (1994) } & \multicolumn{2}{|c|}{ Iashs students } & \multicolumn{2}{|c|}{ Wattelman (1995) } & \multicolumn{2}{|c|}{$\begin{array}{c}\text { Villegas } \\
\text { (1999) }\end{array}$} & \multicolumn{2}{|c|}{$\begin{array}{c}\text { Edmond } \\
(1982)\end{array}$} & \multicolumn{2}{|c|}{$\begin{array}{c}\text { Cardoso } \\
(2000)\end{array}$} \\
\hline male & fem. & male & fem. & male & fem. & male & fem. & male & fem. & male & fem. \\
\hline 1544 & 1887 & 200 & 200 & 50 & 50 & 50 & 50 & 50 & 50 & 50 & 50 \\
\hline 3.6 & 2.8 & 5.3 & 2.9 & 8.0 & 5.0 & 2.0 & 1.5 & 1.0 & 2.0 & 10.2 & 1.9 \\
\hline \multicolumn{2}{|c|}{ both sex } & \multicolumn{2}{|c|}{ both sex } & \multicolumn{2}{|c|}{ both sex } & \multicolumn{2}{|c|}{ both sex } & \multicolumn{2}{|c|}{ both sex } & \multicolumn{2}{|c|}{ both sex } \\
\hline \multicolumn{2}{|c|}{3431} & \multicolumn{2}{|c|}{400} & \multicolumn{2}{|c|}{100} & \multicolumn{2}{|c|}{100} & \multicolumn{2}{|c|}{100} & \multicolumn{2}{|c|}{100} \\
\hline \multicolumn{2}{|c|}{$3.2 \mathrm{~b}$} & \multicolumn{2}{|c|}{$4.1 b$} & \multicolumn{2}{|c|}{$6.5 \mathrm{c}$} & & & \multicolumn{2}{|c|}{$1.5 \mathrm{a}$} & \multicolumn{2}{|c|}{$6.8 \mathrm{c}$} \\
\hline
\end{tabular}

*PS. This is the mean of the sample as whole.

PS. "significant" differences $(a, b, c)$ in term of means = difference in terms of mean between groups $>$ maximum value (6.8) - minimum value (1.5) divided by 4).

\section{Final Considerations}

\section{National Health and Social Life Survey Report in the USA Versus International Students' Data}

Regarding similarities or average behaviors among international students samples versus NHSLS Report, we can list below the following aspects:

1) Close percentage rates of personal importance of sex (45.5\% and $36.5 \%$, respectively) with international female students scoring higher than American females;

2) Similar mean rate of weekly frequency of masturbation (mean 1.6 and 1.6, respectively), although American women masturbate somewhat more;

3) Close mean rate of weekly frequency of heterosexual relations last year (mean 1.9 and 1.7, respectively);

4) Similar mean rate of number of partners in whole life (mean 4.1 and 3.2, respectively).

Regarding the particularities or more discrepant behaviors among international students' samples versus NHSLS Report, we can list below the following aspects:

Higher mean rates of number of heterosexual partners last year for international students.

According to data analyses, I would say that there are greater similarities between females among international students and the NHSLS respondents. Male subjects showed major sexual diversity among international males, as well as in relation to NHSLS Report. Perhaps the globalization phenomenon has a stronger influence on female sexuality in general than among males coming from a patriarchal and macho-men cultures. It is also important to point out that social class is an extremely difficult characteristic to measure, however educational level can be used as a reasonable criterion. Of course, some of my supposed middle class students came from working class, but they were exposed to middle class concepts and lifestyles at local universities.

\section{References}

Allyn, E. (1993). The men of Thailand: 1993 guide to gay Thailand. San Francisco: Bua Luang Publishing Company.
Bell, A. \& Weinberg, M. (1978). Homo-sexualities: a study of diversity among men and women. New York: Simon and Schuster.

Cardoso, F. L. (1994). Orientação sexual masculina em uma comunidade pesqueira. Dissertação de Mestrado, Universidade Federal de Santa Catarina, Florianópolis.

Cardoso, F. L. (2000). 100 Brazilians college students report. Archives of The Institute for Advanced Study of Human Sexuality. Relatório de Pesquisa não publicado: IASHS.

Cardoso, F. L. (2002). "Fishermen" - Masculinity and sexuality in a Brazilian fishing community. Sexuality and Culture ,6(4): 45-72.

Cardoso F. L. \& Werner, D. (2004). Homosexuality. Em C. R. Ember \& M. Ember (Orgs.), Encyclopedia of Sex and Gender, (p. 204215). New Haven: Human relations Area Files

Edmond, A. P. (1982). 100 French Canadian college students report. Archives of The Institute for Advanced Study of Human Sexuality. Relatório de Pesquisa não publicado: IASHS.

Erdoĝan, S. N. (2001). Sexual life in Ottoman society. Istanbul: Donence.

Ford C. \& Beach, F. (1951). Patterns of sexual behavior. New York: ACE Books Inc.

Fry, P. (1982). Para inglês ver. Rio de Janeiro: Zahar.

Fry, P. (1995). Male homosexuality and Afro-Brazilian possession cults. Em S. Murray (Org.), Latin American male homosexualities (pp. 193-220). Albuquerque: New Mexico Press.

Geertz, C. (1978). A Interpretação das Culturas. Rio de Janeiro: Zahar.

Jackson, P. (1999). Tolerant but unaccepting: the myth of a Thai "gay paradise". Em P. Jackson \& N. Cook (Orgs.), Genders \& Sexualities: in modern Thailand (p. 226-242). Bangkok: Silkworm Books.

Janus, S. \& Janus, C. (1993). The Janus report on sexual behavior. New York: John Wiley \& Sons.

Johnson (2001). Emergence: the connected lives of ants, brains, cities and software. New York: Scribner.

Kinsey, A., Pomeroy, W. \& Martin, C. (1948). Sexual behavior in the human male. Philadelphia: Saunders Company.

Kinsey, A., Pomeroy, W., Martin, C. \& Gebhard, P. (1953). Sexual behavior in the human female. Philadelphia: Saunders Company. 


\section{F. L. Cardoso}

Knauft, B. (1986). Text and social practice: narrative "longing" and bisexuality among the Gebusi of New Guinea. Ethos, 14(3), 252-281.

Lago, R. (1999). Bissexualidade masculina: uma identidade negociada. Em M. H. Heilborn (Org.), Sexualidade: o olhar das Ciências Sociais (pp. 157-174). Rio de Janeiro: Zahar.

Laumann, E., Gagnon, J., Michael, R. \& Michaels, S. (1994). The social organization of sexuality: sexual practices in the United States. Chicago: The University of Chicago Press.

Michael, R., Gagnon, J., Laumann, E. \& Kolata, G. (1994). Sex in America: a definitive survey. Boston: Little, Brown and Company.

Money, J. (1998). Sin, science, and the sex police: essays on Sexology \& Sexosophy. New York: Prometheus Book.

Necef, M. (1992). Turkey on the brink of masculinity: a guide for Scandinavian gays. Em A. Schmitt \& J. Sofer (Orgs.), Sexuality and eroticism among males in Moslem societies (pp. 71-75). New York: Harrington Park Press.

Parker, R. (1991). Bodies, pleasures and passions: sexual culture in contemporary Brazil. Boston: Beacon Press.
Reiss, I. (1986). Journey into sexuality: an exploratory voyage. Engel Wood Cliffs: Prentice-Hall.

Rostler, S. \& Mundell, E. (2001). More Americans having gay sex, study shows. Journal of Sex Research, 37, 333-343.

Stoller, R. (1993). Masculinidade e feminilidade: apresentação do gênero. Porto Alegre: Artes Médicas.

Villegas, D. (1999). 100 Colombian college students report. Archives of The Institute for Advanced Study of Human Sexuality. Relatório de Pesquisa não publicado: IASHS.

Waldrop, M. (1992). Complexity: the emergency science at the edge of order and chaos. New York: Simon and Schuster.

Wattelman, D. (1995). 100 Israeli college students report. Archives of The Institute for Advanced Study of Human Sexuality, Relatório de Pesquisa não publicado: IASHS.

Recebido em 25.01.2006

Aceito em 11.09.2006 